Biografistyka Pedagogiczna

Rok 3 (2018) nr 1

ISSN 2543-6112; e-ISSN 2543-7399

DOI: $10.36578 /$ BP.2018.03.05

Aniela Różańska*

\title{
Poczucie obcości wśród swoich jako element biografii jednostek wielokulturowego i wielowyznaniowego Zaolzia
}

\author{
Sense of Alienation among One's Compatriots as Part \\ of the Biographies of Inhabitants of the Multicultural \\ and Multi-faith Region of Zaolzie
}

\begin{abstract}
Zaolzie is a borderland area of the Polish-Czech border where, due to various historical, cultural, ethnic and political conditions, multi-faith and inter-faith identity play a crucial role. The region and its people are characterized by the blurring of clearly defined categories such as "own" and "alien". Nowadays there are more apparent similarities in modes of social life than differences; this results from everyday contacts between representatives of diverse ethnic and religious groups as well as from their fruitful cooperation.

Nonetheless, a powerful process of assimilation among the Polish community is leading to a sense of alienation in the minds of its members and producing the Heidegger-like impression of "not being at home".

The author analyses various autobiographical documents from the standpoint of "alienation inscribed in the home". Further, the author makes an attempt to answer the question of how and to what degree the religious diversity of Zaolzie correlates with its ethnic/national structure. She asks whether faith and Christian caritas could serve as a remedy for cultural alienation and be a step toward building positive attitudes to others, attitudes open to cooperation with people of good will.
\end{abstract}

Key words: sense of alienation, multicultural milieu, national and religious differentiation

* Aniela Różańska - dr hab., pracuje w Zakładzie Pedagogiki Ogólnej i Metodologii Badań na Wydziale Etnologii i Nauk o Edukacji Uniwersytetu Śląskiego, aniela. rozanska@gmail.com. 
Na początku należy odnieść się do terminu Zaolzie i przywołania niektórych faktów związanych z jego powstaniem. Zaolzie jako obszar badawczy znany jest i opisywany wielokrotnie w badaniach pograniczy i ich wielokulturowych społeczeństw, jednakże uważam za stosowne przypomnieć pokrótce jego cechy, zwłaszcza te, odnoszące się do kwestii kulturowych i wyznaniowych.

Pod koniec pierwszej wojny światowej, w 1918 r., Śląsk Cieszyński jako region o strategicznym znaczeniu stał się obiektem sporu między dwoma powstającymi państwami - Rzeczypospolitą i Czechosłowacją. W lipcu 1920 r. Śląsk Cieszyński został - na mocy decyzji Rady Ambasadorów państw ententy w Spa - podzielony pomiędzy Polskę i Czechosłowację. Zachodnia część Śląska Cieszyńskiego, leżąca po lewej stronie Olzy, znalazła się w granicach Czechosłowacji, nazwano ją - ze względu na jej usytuowanie „za Olzą" - Zaolziem¹. Rdzenni mieszkańcy regionu, niepytani o zdanie, gdyż spodziewane referendum nie doszło do skutku, zostali rozdzieleni granicą państwową. Ci, którzy znaleźli się w Czechosłowacji, zaczęli odtąd - jako społeczność zaolziańska - stanowić polską mniejszość narodową. Podział terytorium Śląska Cieszyńskiego zapoczątkował trwające do dziśs ${ }^{2}$ (z przerwą w 1938 r. i w latach okupacji niemieckiej 1939-1945) oddzielenie polskiej społeczności zaolziańskiej od macierzy, wyznaczając jej odmienne losy rozwoju społeczno-kulturowego związane z przynależnością do innego państwa.

Społeczności Zaolzia można rozważać jako społeczności żyjące na pograniczu państwowym, narodowym, etnicznym i kulturowym. Na tym obszarze zbiegały się w przeszłości granice czterech żywiołów etnicznych: polskiego, czeskiego, słowackiego i niemieckiego (nie brakowało też wpływu kultury żydowskiej). Po drugiej wojnie światowej w mozaice narodów zabrakło Żydów i Niemców, a grupą większościową stała się społeczność osób narodowości czeskiej. Współcześnie na Zaolziu stykają się, przenikają i ulegają zmianom elementy różnych kultur, stanowiąc czynnik różnicujący zbiorowości zamieszkujące ten

1 Nazwa Zaolzie funkcjonująca najpierw w publicystyce i języku potocznym, z czasem znalazła miejsce w literaturze naukowej. Jest terminem utworzonym przez Polaków w celu podkreślenia utraconych ziem, które zostały „za Olzą”. W czeskiej literaturze przedmiotu dla tego regionu funkcjonuje nazwa české Těšínsko lub Těšínské Slezsko.

2 Po drugiej wojnie światowej Zaolzie znów stało się częścią Czechosłowacji, a po jej podziale w 1993 r. znalazło się w Republice Czeskiej. 
obszar. Zaolzie jest pograniczem kulturowym w rozumieniu bachtinowskim ${ }^{3}$, na którym specyficzne przenikanie dotyczy zarówno kultur, języków, religii, wartości, zwyczajów, stylów życia i całego dorobku materialnego i duchowego mieszkańców pogranicza.

Dlatego mieszkańcy Zaolzia nie tworzą pod względem narodowościowym, kulturowym czy wyznaniowym monolitu, a raczej - można powiedzieć mozaikę grup etnicznych, narodowościowych i wyznaniowych. Na tym skrawku, liczącym zaledwie $800 \mathrm{~km}$ kwadratowych, koncentruje się życie narodowe, społeczne i kulturowe Polaków w Republice Czeskiej. Tutaj żyją obok siebie Czesi, Polacy, Ślązacy, Słowacy i Romowie. Pod względem wyznaniowym mieszkańcy Zaolzia są także zróżnicowani: katolicy, ewangelicy, niewierzący oraz członkowie kilkunastu mniejszych Kościołów i grup wyznaniowych. Można przyjąć tezę, że to współistnienie różnych narodowości, kultur i wyznań - w większości pokojowe - utworzyło region o niezwykle ciekawej i bogatej kulturze. Jego mieszkańcy mają możliwość dotykania różnych kultur, zwłaszcza polskiej i czeskiej, ale również słowackiej, węgierskiej oraz pozostałości kultury niemieckiej i żydowskiej (mocno obecnych na Śląsku Cieszyńskim do drugiej wojny światowej), mają przywilej współtworzenia i uczestniczenia w bogatych i nieraz skomplikowanych relacjach pomiędzy narodami, społecznościami i jednostkami.

Mniejszość polska w momencie włączenia części Śląska Cieszyńskiego do państwa czechosłowackiego w 1920 r. stanowiła wielotysięczną grupę społeczną polscy historycy mówią o 120-tysięcznej społeczności polskiej ${ }^{4}$, chociaż według czeskiego spisu ludności w $1921 \mathrm{r}$. Zaolzie zamieszkiwała jedynie 68-tysięczna polska grupa narodowościowa. W spisie ludności przeprowadzonym w $1991 \mathrm{r}$. odnotowano około 44 tysięce Polaków zaolziańskich, zaś według spisu ludności w 2001 r. do polskiej grupy mniejszościowej na Zaolziu zgłosiło swą przynależność około 38 tysięcy osób. Liczebność Polaków na Zaolziu ciągle maleje, co gorsza, tendencja spadkowa nasila się, gdyż asymilacja jest nieodzownym

3 Bachtinowskie pogranicze kulturowe to przestrzeń różnorodnych ścierających się ze sobą dyskursów, w której człowiek jest istotą dialogową, to znaczy definiuje swoją tożsamość przez odnoszenie się do innych, ponieważ „zawsze znajduje się na granicy, a zagłębiając się w sobie, patrzy w oczy innemu lub spogląda na siebie oczami innego"; M. Bachtin, Estetyka twórczości słownej, tłum. D. Ulicka, Warszawa 1986, s. 444.

4 W. Sworakowski, Polacy na Śląsku za Olza, Warszawa 1937. 
elementem życia tej grupy mniejszościowej. Jednocześnie wiadomo, że grupy mniejszościowe prawie zawsze wytwarzają wobec asymilacji mechanizmy obronne. Są to mechanizmy pozwalające członkom mniejszości narodowych zachować swoją pierwotną tożsamość etniczną, czyli poczucie przynależności do określonej grupy i jej kultury, którego podstawą jest akceptacja rdzennych wartości tej grupy, świadomość pewnej odrębności od obcych, poczucie związku ze swoimi, świadomość ciągłości i historycznego trwania grupy5.

Jednym ze wskaźników tożsamości narodowej jest posługiwanie się językiem macierzystym przez członków mniejszości narodowych. W przypadku mieszkańców Zaolzia językiem tym nie jest literacki język polski, lecz gwara zachodniocieszyńska, którą posługuje się na co dzień również część Czechów mieszkających na Zaolziu. Posługiwanie się gwarą można uznać za wskaźnik identyfikacji regionalnej, a nie narodowej. Za kryterium polskości należy więc przyjąć nie posługiwanie się językiem polskim, lecz nieużywanie języka czeskiego ${ }^{6}$.

Zaolzie jest specyficznym obszarem pogranicza, na którym - w wyniku różnorakich uwarunkowań historycznych, kulturowych i politycznych - w zróżnicowanie kulturowe, etniczne i językowe wkomponowane jest zróżnicowanie wyznaniowe, widoczne w przynależności mieszkańców do różnych wyznań i Kościołów. Na Zaolziu, podobnie jak w całym regionie Śląska Cieszyńskiego, współistnieją ze sobą dwa główne wyznania: rzymskokatolickie i ewangelickie. Dominującą liczebnie grupę wyznaniową tworzą wierni Kościoła rzymskokatolickiego, drugą co do wielkości grupą są ewangelicy skupieni w Śląskim Kościele Ewangelickim Augsburskiego Wyznania. Znaczny odsetek ludności wyznania ewangelicko-augsburskiego jest cechą specyficzną całego regionu Śląska Cieszyńskiego, począwszy od szesnastowiecznej reformacji. Ewangelicy, choć różnie układały się ich losy, zwłaszcza trudne w czasach prześladowań kontrreformacyjnych, włączyli się - po wydaniu przez cesarza Józefa II w $1781 \mathrm{r}$. Patentu Tolerancyjnego, a zwłaszcza po uzyskaniu pełnego równouprawnienia na mocy Patentu Protestanckiego w 1861 roku - w różnoraką działalność spo-

5 Tak tożsamość etniczną definiuje J. Smolicz, Core Values and Cultural Identity, „Ethnic and Racial Studies", 1 (1981).

6 H. Rusek, Religia i polskość na Zaolziu, Kraków 2002, s. 150.

7 Patent Tolerancyjny z 13 października 1781 r. przyznał ewangelikom pewne prawa, np. umożliwił im budowanie poza murami miasta domów modlitwy bez wieży oraz zakładanie szkół w miejscowościach zamieszkiwanych przez co najmniej 100 rodzin 
łeczną. Aktywnie uczestniczyli w działaniach społeczno-religijnych, oświatowych, w ruchu narodowowyzwoleńczym oraz w wielu innych obszarach spraw publicznych. Posługując się rodzimym językiem w odprawianiu nabożeństw i praktykowaniu innych form kultu, zatroszczyli się nie tylko o rozwój języka ojczystego, ale również o wzmocnienie działalności narodowowyzwoleńczej.

Śląsk Cieszyński jest regionem wielowyznaniowym. Wielowyznaniowość kształtowała się tu począwszy od reformacji przez kilka stuleci. Obecnie na Zaolziu aktywnie działa 12 Kościołów, w przeważającej liczbie protestanckich ${ }^{8}$. Jednak, jak już wspominałam, społeczność zaolziańska podąża w swoim rozwoju - także religijnym - inną drogą niż społeczność Śląska Cieszyńskiego. Będąc pod silnym wpływem kultury czeskiej, przybiera również w obszarze religijności pewne jej cechy. Religijność społeczeństwa czeskiego jest raczej niewielka. W latach powojennych zostało poddane konsekwentnej ateizacji i laicyzacji, co w głównej mierze przyczyniło się do załamania pokoleniowego w przekazie wiary (do odejścia pokolenia rodziców, obecnie już jest to pokolenie dziadków, od religii i Kościoła). Obecnie większość Czechów nie przynależy do żadnego Kościoła, jest bezwyznaniowa, a wiele osób spośród nich jest ateistami ${ }^{9}$. Podobne sekularyzacyjne tendencje, choć nieco słabsze, są widoczne na Zaolziu. Oznacza to, że największą grupę mieszkańców regionu stanowią osoby bezwyznaniowe.

Sytuacja pogranicza umożliwia jej mieszkańcom wzajemne poznanie się i zrozumienie, co daje szanse większej otwartości i akceptacji „inności” narodowościowej, etnicznej, kulturowej, wyznaniowej. To sprawia, że tożsamości społeczne

ewangelickich, ale dopiero Patent Protestancki z 8 kwietnia 1861 r. przyniósł im pełną wolność religijiną i równouprawnienie wobec katolików. Szerzej zobacz: A. Różańska, Działalność edukacyjna Śląskiego Kościoła Ewangelickiego Augsburskiego Wyznania na Zaolziu, Czeski Cieszyn 2002, s. 26 i n.

8 Są to (obok Kościoła rzymskokatolickiego i Śląskiego Kościoła Ewangelickiego Augssburskiego Wyznania) następujące Kościoły: Czeskobraterski Kościół Ewangelicki, Kościół Braterski, Kościół Adwentystów Dnia Siódmego, Kościół Apostolski, Luterański Kościół Ewangelicki, Jednota Braterska w Czechach, Ewangelicki Kościół Metodystów, Braterska Jednota Baptystów, Kościół Husycki, ponadto Związek Wyznania Świadków Jehowy, A. Różańska, Działalność edukacyjna, s. 85.

9 Szerzej na temat religijności Czechów: A. Różańska, Edukacja religijna młodzieży $w$ warunkach pluralizmu religijnego $w$ wybranych krajach Europy Środkowo-Wschodniej (Grupa Wyszehradzka: Polska, Czechy, Słowacja, Węgry) - studium porównawcze, Toruń 2015, S. 292-306, 312-317. 
grup i jednostek zamieszkujących wielokulturowe obszary pogranicza są tożsamościami bardziej otwartymi niż w przypadku osób wywodzących się ze środowisk mniej zróżnicowanych lub jednorodnych kulturowo. Jednocześnie środowisko wielokulturowe powoduje, że tożsamości osób pogranicza kształtują się jako tożsamości wielokrotne, a nieraz rozproszone, niespójne, zagubione w swojej identyfikacji. Jerzy Nikitorowicz dylemat zachowania tożsamości spójnej przez człowieka pogranicza widzi w konflikcie wartości rdzennych, odziedziczonych przez jednostkę, z wartościami innych grup, w których ona, pełniąc różne role społeczne, uczestniczy ${ }^{10}$. Charakter powiązań między kształtowaniem się tożsamości osobowej a kulturą uwypuklił Erik Erikson. Podkreślał on, że kształtowanie osobowości dokonuje się nie tylko pod wpływem biopsychicznych czynników rozwoju i bezpośrednich kontaktów w obrębie stosunków społecznych, ale także w wyniku oddziaływania treści kultury, przenikających się na różnych drogach. W konstytuowaniu się poczucia tożsamości szczególnie podkreślał znaczenie zewnętrznych doświadczeń jednostki jako członka grupy i wewnętrznej solidarności z ideałami grupy $^{11}$. Kategoria ta odnosi się do poczucia solidarności i zespolenia z grupą społeczną i jej wartościami. Dla Eriksona tożsamość pełni rolę czynnika integrującego i scalającego różnorodne, historycznie i kulturowo zmienne doświadczenia jednostki. Na zjawisko różnorodności sytuacji społecznych i kulturowych, szczególnie wyraźnie występujące w rozwoju osobowości kształtującej się na pograniczach grupowych kultur i wpływów zwracała uwagę Antonina Kłoskowska: „Każda sytuacja, w której jednostka staje wobec różnorodności - a zwłaszcza konfliktów - systemów wartości, lojalności, archetypicznych modeli dróg życiowych, rodzi skłonność do wyostrzenia poczucia tożsamości, do jego poszukiwania; często prowadzi do jego kryzysu i rozkładu"12. Jednakże efekt pogranicza, czyli swoisty obszar mediacji między organizmem a wymogami życia społecznego ${ }^{13}$, powoduje

10 J. Nikitorowicz, Pogranicze, tożsamość, edukacja międzykulturowa, Białystok 1995, S. 98-99.

11 E. Erikson, The Problem of Ego Identity, w: Identity and Anxiety, red. M. Stein, A. J. Vidich, D. Manning White, Glencoe 1960, s. 36.

12 A. Kłoskowska, Kulturologiczna analiza biograficzna, „Kultura i Społeczeństwo”, 29 (1985) nr 3, s. 10.

13 L. Witkowski, Ambiwalencja tożsamości z pogranicza kulturowego, w: Edukacja a tożsamość etniczna. Materiały z konferencji naukowej w Rabce, red. M. M. Urlińska, Torun 1995, S. 13 . 
wzbogacanie osobowej tożsamości poprzez oddziaływania innych. W tym procesie wzajemnego oddziaływania i wymieszania ustala się pewna swoista postać egzystencji jednostki, której tożsamość zasługuje na miano wielokulturowej.

W społecznościach zaolziańskich przez lata zacierały się różnice i rysowały podobieństwa między kategoriami „swój” i „obcy”. Dziś istnieje tu więcej podobieństw wzorów życia społecznego niż różnic, a dzięki codziennym kontaktom między przedstawicielami różnych pod względem narodowościowym i religijnym grup ustaliło się wiele form owocnej współpracy społecznej. Niemniej coraz silniejsza asymilacja polskiej społeczności zaolziańskiej potęguje poczucie obcości w świadomości jej członków i przybiera Heideggerowskie znaczenie „bycia nie-w-swoim-domu” ${ }^{\prime 14}$. Nie sama inność w rozumieniu odmienności, lecz inność przekształcona w obcość staje się problemem, zwłaszcza gdy obcość ta wpisana jest niejako w swojskość, a poczucie obcości potęguje się w sytuacji trwogi, kiedy to nie tylko świat społeczny wydaje się jednostce obcy, lecz także ona staje się obca sobie samej.

W niniejszym opracowaniu zamierzam - na przykładzie zwięzłej analizy wypowiedzi autobiograficznych dwóch osób, będących przedstawicielami zaolziańskiej grupy mniejszościowej (mniejszości narodowościowej i religijnej) jednej żyjącej na przełomie xIX i XX w., a drugiej sto lat później, czyli współcześnie - przedstawić, w jaki sposób odnoszą się one wobec „obcości wpisanej w swojskość". Podejmę próbę odpowiedzi na pytanie, czy i jak zróżnicowanie wyznaniowe koreluje ze zróżnicowaniem narodowościowym i w jaki sposób czynniki te wpływają na powstawanie poczucia obcości wśród swoich.

Pierwszą egzemplifikacją osoby pogranicza, która doświadczyła „obcości wpisanej w swojskość" niechaj będą przeżycia biskupa Karola Kotuli, opisane przez autora w książce autobiograficznej.

Autobiografia biskupa Karola Kotuli Od marzeń do ich spetnienia, wspomnienia $z$ lat $1884-1951^{15}$ stanowi cenny wkład do literatury wspomnieniowej dotyczącej Zaolzia, napisana przez osobę wybitną, znaną i szanowaną w Polsce i Europie, dlatego należy spodziewać się, że jego widzenie i percepcja innych są w miarę obiektywne i stonowane.

14 M. Heidegger, Bycie i czas, tłum. B. Baran, Warszawa 1994, s. 267.

15 K. Kotula, Od marzeń do ich spetnienia, wspomnienia z lat 1884-1951, Bielsko-Biała 1998. 
Biskup Karol Kotula (1884-1968) - rodak z Zaolzia, wikariusz w Drogomyślu (1910-1912), katecheta w Polskim Gimnazjum Realnym w Orłowej (1912-1919), wizytator Poznańskiego Okręgu Szkolnego (1919-1927), proboszcz parafii ewangelickiej w Łodzi (1927-1939, 1945-1951), organizator życia polskich ewangelików, w latach 1951-1959 zwierzchnik Kościoła Ewangelicko-Augsburskiego w Polsce.

Karol Kotula urodził się w miejscowości Cierlicko Dolne. Opisując w pamiętniku miejscowość, w której spędził dzieciństwo i młodość, zaskakuje nas niespodziewaną szczegółowością i znajomością realiów życia mieszkańców okolic Cierlicka, dając świadectwo kultywowania tradycji rodzinnej i przywiązania do patriotycznego wychowania.

Dla Kotuli wszystko, co rodzime, jest polskie - polskie są zwyczaje, polskie sympatie, polskie nazwiska. Kiedy natomiast wymienia nazwisko niemieckie, Larisch, pojawia się słowo „piekło“ na wspomnienie miejsca, gdzie „Larisch, właściciel Cierlicka zmuszał chłopów do łamania skał i wywożenia w górę na szczyt Kościelca" ${ }^{16}$. W innym miejscu jednakże pochlebnie wyraża się o niemieckim księgarzu z Cieszyna, który jako jedyny sprowadzał polskie książki, przyczyniając się przez to do szerzenia polskości ${ }^{17}$.

Autor z nostalgią wspomina czasy swego dzieciństwa, kiedy „nad Stonawką nie było słychać innej mowy jak tylko polską" i dodaje: „dziś nad zalew przyjeżdżają autami i motocyklami hałaśliwe tłumy [...], obcym mówiące językiem"18. Następnie opisuje strukturę narodowościową Cierlicka w pierwszej dekadzie XX w.: „Cierlicko było wsią czysto polską. Nie było we wsi ani Niemców (byli zniemczeni chłopi, germanofile), ani Czechów"19, na potwierdzenie tego przytacza wyniki spisu ludności z 1900 i 1910 r.

Pojawia się też nie w pełni klarowny obraz Czecha, którym dla autora był „zniemczony ... zarządca dóbr”, a który „był wszechwładnym panem i odgrywał wielką rolę we wsi"20.

Zaskakuje fakt, że pomimo faworyzowania polskości autor jest świadomy wielokulturowości swego środowiska i z dumą pisze, że „Śląsk Cieszyński był

\footnotetext{
16 Tamże, s. 15.

17 Tamże, s. 26.

18 Tamże, s. 16.

19 Tamże, s. 19.

20 Tamże, s. 17.
} 
schronieniem dla ludzi różnych narodowości, prześladowanych za wiarę oraz kolonistów, wskutek czego było tam dużo obcych nazwisk" ${ }^{21}$.

Przytaczana przez autora przyśpiewka ludowa nie brzmi czysto po polsku, ale na sposób miejscowy, w lokalnej gwarze: „Za gorami torka, torka niezdrzało je, niezdrzało je" ${ }^{\prime 2}$, co dowodzi żywotności gwary w kulturze lokalnej i wyraża sympatie autora dla miejscowej tradycji. Jest on dumny z wyjątkowości swych współrodaków. Są oni dla niego awangardą kultury i wiedzy. Ojciec autora na przykład potrafił nazwać różne gatunki ziół po polsku, niemiecku i łacinie, czytał romantyków polskich i Biblię̨

Dom rodzinny autora był dla niego szczególnym środowiskiem wychowawczym, miejscem transmisji wartości rodzinnych, kultywowanych troskliwie przez rodziców, wartości kulturalnych i religijnych. Co wieczór rodzina odprawiała nabożeństwo domowe. Zarówno podczas nich, jak i rano przed śniadaniem śpiewano pieśni religijne. Matka śpiewała nawet przy zajęciach domowych. Atmosfera w rodzinie była radosna i pogodna, jednak wychowanie nosiło znamiona surowości, charakterystycznej dla wychowania ewangelickiego. Po latach autor wymownie je charakteryzuje: „Pieszczot nie doznawaliśmy, ojciec nie karał nas nigdy, ale jedno jego spojrzenie lub słowo wystarczało i nie było mowy o jakimś nieposłuszeństwie" 24 .

Jego rodzice, jak to było w zwyczaju na Śląsku Cieszyńskim, dużo wysiłku włożyli w edukację dzieci. Ojciec - nauczyciel pomocniczy w wiejskiej szkole, absolwent gimnazjum ewangelickiego w Cieszynie, matka - prosta, skromna, pracowita i rozśpiewana gospodyni domowa, oboje wprowadzali bezpośrednio, przez własny przykład, jak i pośrednio, przez książki polskie, których wiele było w domu, dzieci w świat kultury i nauki. W bibliotece domowej były książki religijne (polskie, niemieckie oraz tłumaczenia z niemieckiego), polska literatura klasyczna, a także podręczniki Jana Śliwki, nauczyciela, autora pierwszych polskich podręczników dla dzieci na Śląsku Cieszyńskim. Mały Karol często czytał książki ojca, przez co nabywał wiedzy oraz zamiłowania do książek.

21 Tamże, s. 19.

22 Tamże, s. 21.

23 Tamże, s. 23-24.

24 Tamże, s. 25. 
Książki uczyły go podstaw patriotyzmu, ale też poszanowania ludzi, niezależnie od narodowości czy wyznania.

Po ukończeniu ludowej szkoły ewangelickiej w Cierlicku Kotula, jak wielu młodych ewangelików śląskich, podjął naukę w polskim gimnazjum w Cieszynie - pierwszej polskiej szkole średniej na Śląsku Cieszyńskim, od 1895 r. prowadzonej przez Macierz Szkolną Księstwa Cieszyńskiego. Tam zetknął się z ruchem narodowym, walczącym w środowisku niemieckim. Należał do zrzeszenia młodzieży gimnazjalnej współpracującego z tajnym stowarzyszeniem „Jedność" w szkołach niemieckich, brał udział w festynach Czytelni Ludowej oraz odczytach i spektaklach teatralnych w Domu Narodowym. Kontakty te określiły jego polityczną świadomość i patriotyczną postawę życiową. Jednocześnie spotykając się z ludźmi różnych narodowości, m.in. w domu nauczyciela Jana Kubisza w Końskiej, nauczył się, że w słusznej sprawie należy współpracować z wszystkimi ludźmi dobrej woli. Doświadczenie to okazało się później bardzo jemu przydatne, kiedy pracując jako polski ksiądz w niemieckojęzycznej w większości parafii łódzkiej dążył do pojednania i współpracy między zwaśnionymi narodowościowo ewangelikami ${ }^{25}$.

Kotula kontynuował studia teologiczne w Wiedniu. Okres studiów uświadomił mu rolę Austriaków w zniewoleniu Polski, ale także ich wkład w rozwój jego regionu. Wyraża się pozytywnie o samych Austriakach i cytuje podział studentów na trzy grupy językowe: liczną niemiecką, polską i czeską ${ }^{26}$. Po studiach pracował w środowisku niemieckojęzycznym, ale obawiając się zasymilowania, przenosi się w 1910 r. do Drogomyśla. Poruszał problem „ślązakowców“ i działalności Józefa Kożdonia ${ }^{27}$, zawsze opowiadając się za Polską i sprawą polskości Śląska Cieszyńskiego.

Od 1912 r. pracował jako katecheta i nauczyciel języka niemieckiego w gimnazjum realnym w Orłowej, broniąc prawa „ludu piastowskiego"28 do własnej tożsamości wobec nacisków niemieckich i czeskich. Szczególnie krytycznie przygląda się planowej i systematycznej czechizacji regionu Zaolzia, z przykrością stwierdzając, że „setki tysięcy Polaków z zachodniej Galicji, którzy przybyli

\footnotetext{
25 Tamże, s. 140-142.

26 Tamże, s. 52.

27 Tamże, s. 73.

28 Tamże, s. 77.
} 
do pracy, uległy czechizacji" ${ }^{29}$. Oskarża Czechów o tworzenie swych instytucji równoległych do polskich, na przykładzie powstałego w Orłowej w 1909 r. polskiego gimnazjum realnego i niemalże równocześnie, naprzeciw - gimnazjum czeskiego. Podsumowuje tymi słowami:

To, co się dzisiaj nieraz głosi i pisze, że gimnazja w Orłowej, polskie i czeskie, były bratnimi instytucjami, [...] jest tylko częściowo prawdą [...], szkoły były pod względem politycznym konkurencyjnymi ${ }^{30}$.

Gdyby przyjąć za prawdziwy obraz szkoły polskiej naszkicowany przez autora, wychodziłaby z tej konkurencji zwycięsko:

Gimnazjum stało pod każdym względem na wysokim poziomie. [...] Grono nauczycielskie odznaczało się wielką sumiennością, pracowitością i odpowiedzialnością. [...] Przedmiotem starań i pracy gimnazjum był nie tylko poziom umysłowy uczniów, pomyślano też o kształceniu charakterów. Temu celowi miało służyć harcerstwo ${ }^{31}$.

Jakkolwiek gimnazjum realne w Orłowej miało istotnie wysoki poziom nauczania, to przedstawienie go jako idealnej niemalże placówki wynika z pewnych resentymentów autora.

Z doświadczeń zyskanych w wielokulturowej społeczności Śląska Cieszyńskiego ks. Kotula niejednokrotnie korzystał w pracy kościelnej, społecznej i politycznej, zarówno w Poznaniu i Łodzi w okresie międzywojennym, jak też w bardzo trudnej, bo prowadzonej w atmosferze nieufności ${ }^{32}$, powojennej działalności, najpierw jako proboszcz w Łodzi, później jako zwierzchnik Kościoła Ewangelicko-Augsburskiego.

Cieszył się zawsze wielkim autorytetem wśród współpracowników, przyjaciół, był też ceniony i poważany przez ludzi niezwiązanych ze społecznością ewangelicką. Był postrzegany jako człowiek rozumiejący kulturowo innych, otwarty na innych, współpracujący z innymi. Jednakże konsekwentnie działał przeciwko stereotypowemu postrzeganiu mniejszości zarówno tej polskiej na Zaolziu, jak

29 Tamże, s. 79.

30 Tamże, s. 80.

31 Tamże, s. 82-83.

32 Tamże, s. 213. 
i mniejszości ewangelickiej w Polsce. Chodziło mu o to, by zniknął jakże często spotykany w Polsce powojennej stereotyp Polaka-katolika i ewangelika-Niemca, żeby wyznanie nie było utożsamiane z narodowością. Chociaż opuścił Zaolzie i wybrał życie w Polsce, zawsze z radością wracał w rodzinne strony. Jego kolejnym powrotom towarzyszył jednak coraz większy smutek, wynikający z poczucia obcości wśród swoich i niezgody na obserwowane zmiany w lokalnej społeczności, zwłaszcza rezygnnacji z piękna ojczystego języka - gwary cieszyńskiej, czemu niejednokrotnie dawał wyraz w autobiografii.

Analizę autobiograficzną zawężono przede wszystkim do okresu życia i działalności autora na Śląsku Cieszyńskim. Pominięty został jakże owocny okres działalności bpa Kotuli w Polsce międzywojennej i powojennej. Uczyniono tak, gdyż dla kształtowania się kluczowych elementów tożsamości wielokulturowej autora najważniejszy był okres młodości spędzony w sytuacji wielokulturowego pogranicza. Drugim powodem ograniczenia analizy biografii do wątków zaolziańskich był cel niniejszych rozważań - wskazanie na sposób odnoszenia się autora wobec poczucia obcości wśród swoich.

Drugą egzemplifikacją człowieka pogranicza jest osoba żyjąca współcześnie, na przełomie XX i XXI w., która chciała pozostać anonimową ${ }^{33}$. Jest podobnie jak jej poprzednik przedstawicielem polskiej mniejszości zaolziańskiej, aktywnym członkiem Kościoła ewangelickiego (ŚKEAW). Wychowany w wierzącej rodzinie wielodzietnej, w której rodzice pomimo niezbyt dobrych warunków materialnych umożliwili wszystkim dzieciom uzyskanie wykształcenia na poziomie uniwersyteckim, z estymą wspomina lata młodości i trud rodziców włożony w wychowanie dzieci:

od najwcześniejszych lat zachęcali nas do czytania książek, zwłaszcza Biblia była w domu czytana codziennie. Wychowali nas w poczuciu wartości nauki i dopilnowali, aby była dla nas miłym obowiązkiem.

Jego dzieciństwo i młodość przypadły na niezbyt przyjazne czasy dla ludzi, którzy należeli do Kościoła i nie ukrywali swojej wiary ${ }^{34}$. Pomimo tego jego

33 Dane autobiograficzne zostały pozyskane w kilku wywiadach swobodnych przeprowadzonych z rozmówcą.

34 Lata siedemdziesiąte i osiemdziesiąte $\mathrm{xx}$ w. to okres tzw. normalizacji w Czechosłowacji, kiedy za każdą wykrytą działalność religijną, czyli za popełnione „czyny 
rodzice byli aktywnymi członkami Kościoła ewangelickiego, organizatorami życia religijnego i społeczno-kulturalnego parafii. On zaś należał do parafialnej grupy młodzieżowej, zespołu muzycznego, chóru mieszanego i męskiego. $\mathrm{W}$ jego domu rodzinnym odbywały się tajne spotkania młodzieżowe, jeśli nie mogły mieć miejsca na parafii. Przez pewien okres drukowano też na powielaczu gazetkę młodzieżową. Rozmówca uważa, że z pespektywy minionych lat ważne jest

przypominanie tamtych minionych czasów, które były złe, bo nie dawały nam wolności religijnej, ale i dobre, bo docenialiśmy każdą możliwość spotykania się i bycia razem.

Jeśli chodzi o postrzeganie ludzi innych narodowości i wyznań, rozmówca reprezentował otwartą postawę wobec nich. Przychylnie wypowiadał się o katolikach, wśród których ma wielu przyjaciół. Wspominał między innymi wycieczki w góry młodzieży katolickiej i ewangelickiej organizowane potajemnie w latach reżimu komunistycznego. „Doświadczenie wzajemnej pomocy i wsparcia pozwoliło nam zrozumieć, że ważniejsze jest to, co nas łączy, a nie, co różni". Uważa, że wcześniejsze doświadczenia przełożyły się na współczesne relacje między przedstawicielami różnych wyznań protestanckich i katolickich oraz ekumeniczną współpracę, która jest na Zaolziu zjawiskiem powszechnym.

Jego stosunek wobec osób narodowości czeskiej jest równie otwarty i życzliwy. „Chodziłem z Czechami do tej samej podstawówki, przerwy mieliśmy wspólne, a na zajęcia rozchodziliśmy się do różnych klas. To byli nasi koledzy". Wiele razy i w różnych sytuacjach doświadczył dobrych relacji z osobami narodowości czeskiej. Niemniej w ostatnich latach, kiedy coraz częściej w najbliższym środowisku (rodzinnym, parafialnym, lokalnym) słyszy język czeski zamiast języka polskiego lub gwary, ogarnia go uczucie wyobcowania i osamotnienia. Nie może zrozumieć, dlaczego „nasi ludzie dobrowolnie rezygnują z naszego języka"? Pomimo doświadczanych rozterek uważa, że wspólna praca i chrześcijańska caritas łączą ludzi różnych narodowości i pozwalają na przezwyciężanie narodowościowych podziałów.

antypaństwowe" groziły sankcje. W wyniku masowej inwigilacji w społeczeństwie panował strach, ludzie coraz częściej wybierali spokój i rozluźniali więzi z Kościołem. Szerzej zobacz: A. Różańska, Edukacja religijna, s. 304-306. 
Porównując wątki biograficzne współczesnych osób z autobiografią ks. Kotuli, można znaleźć pewne elementy wspólne, wyznaczniki postawy ludzi, dla których podstawowe wartości grupy, do której należą - kultura, język, religia - są niezwykle ważne.

W obu przypadkach czynnikiem powodującym poczucie obcości wśród swoich jest asymilacja polskiej grupy mniejszościowej. W XIX w. zagrożenie dla kultury i tożsamości polskiej grupy mniejszościowej stanowili Niemcy, a później Czesi ${ }_{2}$ co przejawiało się w stosowaniu języka niemieckiego/czeskiego zamiast języka polskiego czy gwary w sytuacjach życia codziennego. Obecnie asymilacja polskiej grupy mniejszościowej zachodzi wobec większościowej grupy czeskiej. Podobnie jak dawniej, zagrożona jest mowa ojczysta - wyrażana w gwarze zachodniocieszyńskiej. Świadome zastępowanie jej językiem czeskim w sytuacjach formalnym, a nawet nieformalnych życia codziennego, przez przedstawicieli polskiej mniejszości jest czynnikiem świadczącym o szybkiej asymilacji Polaków zaolziańskich, jak też o coraz mniejszym poczuciu własnej tożsamości narodowej i kulturowej.

Jednocześnie wartości religijne - wiara, świadectwo życia, chrześcijańska caritas i współpraca ekumeniczna chrześcijan, jeśli są dla jednostek wartościami nadrzędnymi, mogą stanowić antidotum na ogarniające je poczucie obcości wśród swoich, spowodowane coraz większą asymilacją osób ich własnej grupy mniejszościowej.

Inna jest jednak współczesna rola Kościoła na Zaolziu. Dawniej Kościoły zarówno rzymskokatolicki, jak i ewangelicki - pełniły na Zaolziu rolę instytucji kultywującej i podtrzymującej polskość - to przede wszystkim dzięki nim utrzymana została polska kultura i edukacja w polskich szkołach. Dziś w Kościele asymilacja jest widoczna w takiej samej mierze, jak w innych instytucjach publicznych. Kościół nie pełni funkcji integrującej wobec kwestii dotyczących tożsamości narodowej. Niemniej doświadczenia jednostek w trakcie różnych działań na niwie chrześcijańskiej diakonii i caritas oraz współpraca chrześcijan różnych wyznań mogą być lekarstwem na wyobcowanie kulturowe i drogą do budowania pozytywnych postaw wobec innych, postaw otwartych na współpracę ludzi dobrej woli.

Streszczenie: Zaolzie jest specyficznym obszarem pogranicza polsko-czeskiego, na którym - w wyniku różnorakich uwarunkowań historycznych, kulturowych i politycznych w zróżnicowanie kulturowe i etniczne pogranicza - wkomponowane jest zróżnicowa- 
nie wyznaniowe, jako charakterystyczny wymiar regionu. W społecznościach zaolziańskich przez lata zacierały się różnice i rysowały się podobieństwa między kategoriami „swój” i „obcy”. Dziś istnieje tu więcej podobieństw wzorów życia społecznego niż różnic, a dzięki codziennym kontaktom między przedstawicielami różnych pod względem narodowościowym i religijnym grup ustaliło się wiele form owocnej współpracy społecznej. Niemniej coraz silniejsza asymilacja polskiej społeczności zaolziańskiej potęguje poczucie obcości w świadomości jej członków i przybiera heideggerowskie znaczenie „bycia nie-w-swoim-domu”. Autorka przedstawia na przykładzie analizy wypowiedzi autobiograficznych, sposób odnoszenia się wobec „obcości wpisanej w swojskość”. Podejmuje próbę odpowiedzi na pytanie, czy i jak zróżnicowanie wyznaniowe koreluje ze zróżnicowaniem narodowościowym? Czy wiara i chrześcijańska caritas mogą być lekarstwem na wyobcowanie kulturowe i drogą do budowania pozytywnych postaw wobec innych, postaw otwartych na współpracę ludzi dobrej woli.

Słowa kluczowe: poczucie obcości, środowisko wielokulturowe, zróżnicowanie narodowościowe, zróżnicowanie wyznaniowe

\section{Bibliografia}

Bachtin M., Estetyka twórczości słownej, tłum. D. Ulicka, Warszawa 1986.

Erikson E., The problem of Ego Identity, w: Identity and Anxiety, red. M. Stein, A. J. Vidich, D. Manning White, Glencoe 1960.

Heidegger M., Bycie i czas, tłum. B. Baran, Warszawa 1994.

Kłoskowska A., Kulturologiczna analiza biograficzna, „Kultura i Społeczeństwo”, 29 (1985) nr 3.

Kotula K., Od marzeń do ich spełnienia, wspomnienia z lat 1884-1951, Bielsko-Biała 1998. Różańska A., Działalność edukacyjna Śląskiego Kościoła Ewangelickiego Augsburskiego Wyznania na Zaolziu, Czeski Cieszyn 2002.

Różańska A., Edukacja religijna młodzieży w warunkach pluralizmu religijnego w wybranych krajach Europy Środkowo-Wschodniej (Grupa Wyszehradzka: Polska, Czechy, Słowacja, Węgry) - studium porównawcze, Toruń 2015.

Różańska A., Tożsamość religijna dzieci uczących się w polskich szkołach za granica, w: Tożsamość kulturowa, religijność i edukacja religijna postrzegana z perspektywy społeczności polskich szkół na obczyźnie, red. E. Ogrodzka-Mazur, U. Klajmon-Lech, A. Różańska, Cieszyn-Toruń 2014.

Rusek H., Religia i polskość na Zaolziu, Kraków 2002.

Smolicz J., Core values and cultural identity, „Ethnic and Racial Studies”, 1 (1981).

Witkowski L., Ambiwalencja tożsamości z pogranicza kulturowego, w: Edukacja a tożsamość etniczna. Materiały z konferencji naukowej w Rabce, red. M. M. Urlińska, Toruń 1995. 
